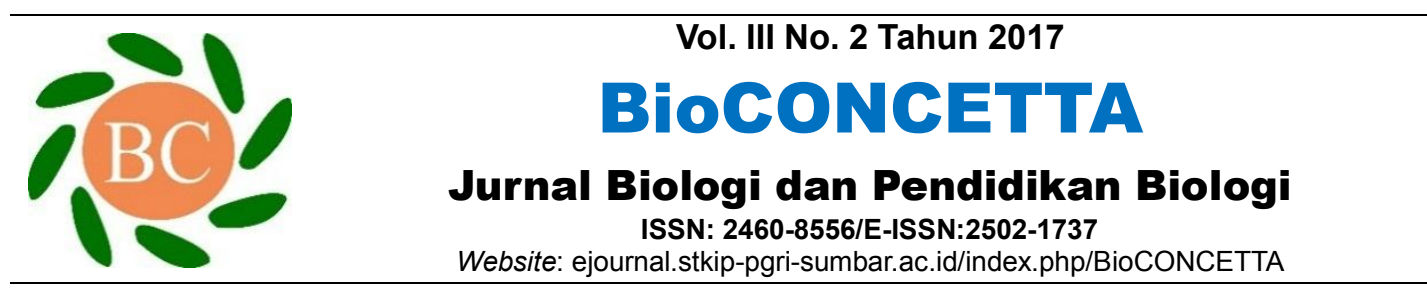

\title{
Persepsi Guru Pamong Terhadap Profesional Mahasiswa Praktek Lapangan Kependidikan
}

Darmanella Dian EkaWati

Program Studi Pendidikan Biologi FKIP Universitas Mahaputra Muhammad Yamin Jl. Jenderal Sudirman No. 6 Kp. Jawa Tj. Harapan Solok, Sumatera Barat (27317), Indonesia E-mail:eka22darmanell@gmail.com

Info Artikel

Sejarah Artikel

Diterima:

15 Agustus 2017

Disetujui:

27 September 2017

Dipublikasikan:

4 Desember 2017

Kata Kunci:

persepsi, profesional, guru pamong

Keywords: perception, professional, teacher tutors

\begin{abstract}
Abstrak
Penelitian ini bertujuan untuk mengetahui bagaimana persepsi guru pamong terhadap kompetensi profesional mahasiswa Praktek Lapangan Kependidikan (PLK). Teknik pengambilan sampel menggunakan total sampling. Teknik pengumpulan data berupa angket. Jenis angket yang digunakan jenis angket tertutup dengan bentuk Ceklist. Teknik analisis data yang digunakan adalah analisis statistik deskriptif. Berdasarkan data hasil penelitian diketahui bahwa persepsi guru pamong terhadap kompetensi mahasiswa PLK dalam menguasai bahan pembelajaran, mengelola proses pembelajaran, menilai prestasi belajar peserta didik, mengelola kelas, mengelola interaksi belajar mengajar termasuk kategori baik sekali, dan menggunakan media termasuk kategori baik

Abstract

This study aims to find out how the perception of teachers tutor to professional competence of students Field Training Practices. The sampling technique uses total sampling. Data collection techniques are questionnaires. The type of questionnaire used is a closed questionnaire type with a checklist form. Data analysis technique used is descriptive statistical analysis. Based on the research data, it is known that teachers 'perceptions of the competence of Field Training Practices students in mastering the learning materials, managing the learning process, assessing the students' learning achievement, managing the class, managing the teaching and learning interaction including the excellent category, and using media including good category
\end{abstract}




\section{PENDAHULUAN}

Guru diharapkan dapat melakukan tugas dan kewajibannya secara profesional agar tujuan pendidikan dapat tercapai. Profesionalitas seorang guru ditentukan oleh empat kompetensi, yaitu kompetensi pedagogik, kompetensi kepribadian, kompetensi sosial, kompetensi profesional. Calon guru perlu dibekali dengan berbagai pengalaman baik teoritis maupun pengalaman praktis agar nanti bias menjadi seorang guru profesional.

PLK merupakan salah satu kegiatan akademik yang dilakukan oleh mahasiswa sebagai calon guru dalam rangka meningkatkan kompetensi pedagogik, profesional, sosial dan kepribadian di lingkungan sekolah. Buku Pedoman Praktek Lapangan Kependidikan UMMY Solok (2010:1) tertulis bahwa Program Praktek Lapangan Kependidikan (PLK) merupakan salah satu kegiatan intra kurikuler yang dilaksanakan oleh mahasiswa yang mencakup, baik latihan mengajar maupun tugas-tugas kependidikan diluar mengajar secara terbimbing dan terpadu untuk memenuhi persyaratan profesi kependidikan. PLK merupakan salah satu mata kuliah yang wajib diambil oleh setiap mahasiswa program studi kependidikan. Kegiatan PLK ini dilakukan oleh mahasiswa selama 1 semester atau selama 6 bulan di sekolah yang sudah ditetapkan oleh jurusan.

Pentingnya peranan kegiatan PLK ini sangat membutuhkan bantuan, arahan serta bimbingan dari guru-guru yang ada disekolah tempat pelaksanaan kegiatan PLK. Guru yang ditunjuk secara khusus dalam membimbing mahasiswa biasa disebut sebagai Guru Pamong. Menurut Wardani dan Suparno (1994: 26) Guru Pamong adalah guru yang ditugasi membimbing mahasiswa calon guru selama mengikuti PLK. Guru Pamong memiliki peranan yang sangat penting dalam memberikan bimbingan dan latihan kepada mahasiswa dalam melakukan keterampilan mengajar seperti keterampilan mempersiapkan perangkat pembelajaran (Silabus, RPP, Media, Modul, dan perangkat penilaian), keterampilan membuka pelajaran, menjelaskan pembelajaran, memberikan stimulus, bertanya, memberikan penguatan serta menutup pelajaran.

Berdasarkan hasil monitoring 
terhadap pelaksaaan kegiatan PLK di sekolah yang peneliti lakukan pada semester ganjil tahun ajaran 20152016, beberapa guru pamong menyampaikan berbagai keluhan seperti ada mahasiswa kurang memahami materi ajar, kurang mampu mempersiapkan perangkat pembelajaran, kurang memiliki percaya diri dalam melakukan praktek mengajar, dan ada juga yang kurang mampu dalam mengelola kelas.

Semua keluhan yang disampaikan guru pamong tentang kompetensi profesional mahasiswa tersebut merupakan gambaran persepsi Guru Pamong terhadap mahasiswa yang melakukan PLK. Dalam pelaksanaan kegiatan PLK masingmasing Guru Pamong memiliki persepsi sendiri tentang mahasiswa yang dibimbingnya. Persepsi dapat dipahami dengan melihatnya sebagai suatu proses seseorang mengorganisasikan serta menginterpretasikan kesan-kesan sensorinya dalam usahanya memaknai lingkungannya (Siagian, 2004: 100).

Semakin bagus persepsi guru pamong terhadap mahasiswa bimbingangnya maka akan semakin bagus juga hubungan social dan interaksi serta pelaksanaan bimbingan yang diberikan. Oleh karena itu penulis tertarik untuk melihat bagaimana persepsi Guru Pamong terhadap mahasiswa PLK dengan judul "Persepsi Guru Pamong terhadap Kompetensi Profesional Mahasiswa Praktek Lapangan Kependidikan (PLK) Program Studi Pendidikan Biologi UMMY Solok Pada Tahun Ajaran 2016-2017 "Penelitian ini bertujuan untuk mengetahui bagaimana persepsi guru pamong terhadap kompetensi professional mahasiswa Praktek Lapangan Kependidikan (PLK) Program Studi Pendidikan Biologi UMMY Solok Pada Tahun Ajaran 2016-2017.

\section{BAHAN DAN METODE}

Penelitian ini merupakan penelitian deskriptif yang termasuk pada jenis penelitian survai. Pada penelitian ini, populasi yang digunakan adalah semua Guru Pamong yang membimbing mahasiswa Program Studi Pendidikan Biologi FKIP UMMY Solok semester VII tahun ajaran 2016/2017 dalam melakukan kegiatan PLK yang berjumlah 12 orang. Sedangkan sampel diambil dengan menggunakan 
total sampling adalah seluruh guru pamong yang membimbing mahasiswa Program Studi Pendidikan Biologi FKIP UMMY Solok semester VII tahun ajaran 2016/2017 dalam melakukan kegiatan PLK yang berjumlah 12 orang. Penelitian ini dilaksanakan di sekolah pelaksana kegiatan PLK direncanakansebanyak 12 sekolah yang ada di kotaSolok yang terdiridari 6 buah SMP, 1 buah MAN, dan 4 buah SMA.

Data dalam penelitian ini adalah data primer, yaitu berupa data angket yang langsung diisi oleh Guru Pamong yang membimbing mahasiswa Program Studi Pendidikan Biologi FKIP UMMY Solok semester VII tahun ajaran 2016/2017 dalam kegiatan PLK yang berjumlah12 orang. Untuk mendapatkan data yang diperlukan dalam penelitian ini digunakan teknik pengumpulan data berupa angket. Dalam penelitian ini yang digunakan jenis angket tertutup dengan bentuk rating scale, yaitu kuesioner yang telah tersedia jawabannya yang ada. Bentuk angket yang digunakan dalam penelitian ini adalah checklist dengan lima pilihan jawaban yaitu $\mathrm{BS}=$ baik sekali, $\mathrm{B}=$ baik, $\mathrm{C}=$ cukup, $\mathrm{K}=$ kurang, dan $\mathrm{KS}$ $=$ kurang sekali.

Berdasarkan tujuan penelitian dan pertanyaan penelitian, maka teknik analisis data yang digunakan adalah analisis statistik deskriptif dengan menggunakan rumus berikut.

Mean $=\frac{\text { Jumlah Skor }}{\text { Banyak Data }}$

kriteria persepsi guru pamong terhadap kompetensi profesional mahasiswa praktek lapangan kependidikan (PLK) pada Program Studi Pendidikan Biologi terdapat pada Tabel 1.

Tabel 1. Kriteria Persepsi

\begin{tabular}{cc}
\hline Koefisien Persepsi & Kriteria \\
\hline $4,00<\mathrm{PM} \leq 5,00$ & Baik Sekali \\
$3,00<\mathrm{PM} \leq 4,00$ & Baik \\
$2,00<\mathrm{PM} \leq 3,00$ & Cukup \\
$1,00<\mathrm{PM} \leq 2,00$ & Kurang \\
$0,00 \leq \mathrm{PM} \leq 1,00$ & Sangat Kurang \\
\hline
\end{tabular}

Dimodifikasi dari Arikunto, 2009. 


\section{HASIL DAN PEMBAHASAN}

Penelitian tentang persepsi Guru Pamong terhadap kompetensi profesional mahasiswa Praktek Lapangan Kependidikan (PLK) pada program studi Pendidikan Biologi ditinjau dari enam aspek yaitu penguasaan bahan pengajaran, pengelolaan proses belajar mengajar, penilaian prestasi belajar peserta didik, pengelolaan kelas, penggunaan media belajar dan interaksi hasil belajar mengajar.

\section{Penguasaan Bahan Pengajaran}

Menguasai bahan pengajaran merupakan tuntutan yang wajib harus dipenuhi oleh mahasiswa PLK sebagai calon guru untuk bisa melakukan praktek mengajar didalam kelas. Dengan menguasai bahan pengajaran atau materi yang akan diajarkan maka mahasiswa PLK akan lebih memiliki percaya diri dalam melakukan proses mengajar untuk mentransfer ilmu kepada peserta didik yang diajarnya.

Tabel 2. Persepsi Guru Pamong terhadap Penguasaan Bahan Pengajaran Mahasiswa PLK

\begin{tabular}{rlcc}
\hline No & \multicolumn{1}{c}{ Indikator } & Rata-rata & Kriteria \\
\hline 1 & $\begin{array}{l}\text { Menguasai bahan bidang studi dalam } \\
\text { kurikulum sekolah }\end{array}$ & 4,42 & Baik sekali \\
2 & $\begin{array}{l}\text { Menguasai bahan pengayaan /penunjang } \\
\text { bidang studi }\end{array}$ & 3,81 & Baik \\
\hline
\end{tabular}

Berdasarkan hasil pengolahan data penelitian yang terdapat pada Tabel 2 dapat diketahui bahwa persepsi Guru Pamong terhadap kemampuan mahasiswa PLK dalam menguasai bahan pengajaran bidang studi sesuai dengan yang ada di kurikulum sekolah termasuk kategori baik sekali sedangkan untuk penguasaan bahan pengayaan atau bahan penunjang bidang studi termasuk kategori baik.

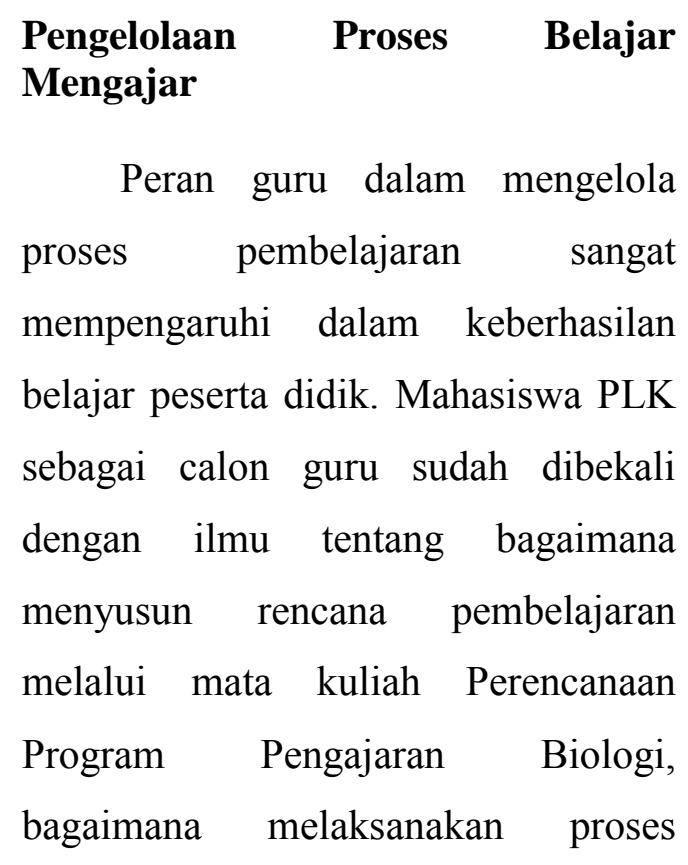


pembelajaran pada matakuliah Strategi

Belajar Biologi dan Microteaching.

Tabel 3. Persepsi Guru Pamong Terhadap Kemampuan Mahasiswa PLK dalam Pengelolaan Proses Belajar Mengajar

\begin{tabular}{rlcc}
\hline No & \multicolumn{1}{c}{ Indikator } & Rata-rata & Kriteria \\
\hline 1 & Menyusun rencana pembelajaran & 4,33 & Baik sekali \\
2 & Melaksanakan proses pembelajaran & 4,08 & Baik sekali \\
\hline
\end{tabular}

Sumber : Hasil penelitian yang diolah

Berdasarkan hasil pengolahan mengelola proses pembelajaran dengan data penelitian yang terdapat pada baik sekali.

Tabel 3 dapat diketahui bahwa persepsi guru pamong terhadap kemampuan mahasiswa PLK dalam menyusun rencana pembelajaran termasuk

\section{Menilai Prestasi Belajar Peserta Didik}

Seorang guru harus bisa berperan kategori baik sekali sedangkan kemampuan mahasiswa PLK dalam melaksanankan proses pembelajaran sebagai evaluator yang baik untuk dapat menilai prestasi belajar peserta didiknya. Melalui penilaian guru dapat mengetahui keberhasilan pencapaian juga termasuk kategori baik sekali. tujuan pembelajaran, penguasaan Data penelitian ini menunjukkan bahwa Guru Pamong berpendapat bahwa peserta didik terhadap materi yang sudah dipelajarinya, serta ketepatan mahasiswa PLK sudah mampu dan keefektifan metode pembelajaran yang digunakan.

Tabel 4. Persepsi Guru Pamong terhadap Kemampuan Mahasiswa PLK dalam Menilai Prestasi Peserta Didik

\begin{tabular}{rlcc}
\hline No & \multicolumn{1}{c}{ Indikator } & Rata-rata & Kriteria \\
\hline 1 & Menyusun rencana penilaian & 4,08 & Baik sekali \\
2 & Melaksanakan penilaian & 4,25 & Baik sekali \\
3 & Mengolah, menganalisis dan menyusun & 4,31 & Baik sekali \\
& laporan hasil penilaian & & \\
4 & Melaksanakan tindak lanjut hasil penilaian & 4,13 & Baik sekali \\
\hline Sumber : Hasil penelitian yang diolah
\end{tabular}

Berdasarkan hasil pengolahan data penelitian yang terdapat pada
Tabel 4 dapat diketahui bahwa persepsi Guru Pamong terhadap kemampuan 
mahasiswa PLK dalam menilai prestasi peserta didik sudah baik sekali, baik dalam menyusun rencana penilaian, melaksanakan penilaian, mengolah, menganalisis dan menyusun laporan serta melaksanakan tindak lanjut hasil penilaian.

\section{Pengelolaan Kelas}

Seorang guru harus mampu mengelola kelas dengan baik agar proses pembelajaran dapat berjalan dengan efektif dan tujuan pembelajaran dapat dicapai dengan baik. Sekolah tempat pelaksanaan PLK merupakan tempat belajar bagi mahasiswa PLK tentang bagaimana cara mengelola kelas dengan baik, bagaimana menghadapi siswa didalam kelas sehingga proses pembelajaran dapat berlangsung dengan baik.

Tabel 5. Persepsi Guru Pamong terhadap Kemampuan Mahasiswa PLK dalam Pengelolaan Kelas

\begin{tabular}{rlcc}
\hline No & \multicolumn{1}{c}{ Indikator } & Rata-rata & Kriteria \\
\hline 1 & $\begin{array}{l}\text { Mengatur tata ruang kelas untuk } \\
\text { pengajaran }\end{array}$ & 4,08 & Baik sekali \\
2 & $\begin{array}{l}\text { Menciptakan iklim belajar mengajar } \\
\text { yang kondusif }\end{array}$ & 3,96 & Baik \\
Sumber : Hasil penelitian yang diolah & &
\end{tabular}

Berdasarkan hasil pengolahan data penelitian yang terdapat pada Tabel 5 dapat diketahui bahwa persepsi guru pamong terhadap kemampuan mahasiswa PLK dalam mengatur tata ruang kelas yang dapat mendukung kenyamanan dalam proses pebelajaran baik sekali sedangkan kemampuan mahasiswa PLK dalam menciptakan iklim belajar mengajar yang kondusis termasuk kategori baik.

\section{Penggunaan Media Belajar}

Guru yang efektif dalam menggunakan media dapat meningkatkan minat peserta didik dalam proses belajar mengajar sehingga peserta didik dapat lebih cepat dan mudah memahami materi pelajaran yang disampaikan guru. Mahasiswa PLK sebelum melaksanakan kegiatan PLK juga sudah dibelakai dengan ilmu tentang media pembelajaran dan sudah mencoba membuat beragam media pembelajaran melalui mata kuliah media pembelajaran. 
Tabel 6. Persepsi Guru Pamong terhadap Kemampuan Mahasiswa PLK dalam Menggunakan Media Belajar

\begin{tabular}{rlcc}
\hline No & \multicolumn{1}{c}{ Indikator } & Rata-rata & Kriteria \\
\hline 1 & $\begin{array}{l}\text { Mengenal, memilih dan menggunakan } \\
\text { sesuatu media }\end{array}$ & 4,08 & Baik sekali \\
2 & $\begin{array}{l}\text { Membuat alat-alat bantu pengajaran } \\
\text { yang sederhana. }\end{array}$ & 3,71 & Baik \\
3 & $\begin{array}{l}\text { Penggunaan fasilitas pendukung dalam } \\
\text { pengajaran }\end{array}$ & 4,04 & Baik sekali \\
\hline Sumber : Hasil penelitian yang diolah
\end{tabular}

Berdasarkan hasil pengolahan data penelitian yang terdapat pada Tabel 6 dapat diketahui bahwa persepsi guru pamong terhadap kemampuan mahasiswa PLK dalam mengenal, memilih dan menggunakan sesuatu media adalah baik sekali, mahasiswa juga dinilai baik dalam membuat alatalat bantu pengajaran yang sederhana dan baik sekali dalam menggunakan fasilitas pendukung dalam pembelajaran.

\section{Interaksi BelajarMengajar}

Interaksi belajar mengajar terjadi antara guru dan peserta didik. Guru haruslah dapat membangun iteraksi yang komunikatif yang dapat memfasilitasi terjadinya proses belajar serta dapat memberikan motivasi sehingga mampu memberikan dorongan dan semangat belajar bagi peserta didik.

Tabel 7. Persepsi Guru Pamong Terhadap Kemampuan Mahasiswa PLK dalam Melakukan Interaksi Belajar Mengajar

\begin{tabular}{clcc}
\hline No & \multicolumn{1}{c}{ Indikator } & Rata-rata & Kriteria \\
\hline 1 & $\begin{array}{l}\text { Berinteraksi dengan peserta didik secara } \\
\text { komunikatif }\end{array}$ & 4,36 & Baik sekali \\
2 & Memotivasi peserta didik & 4,09 & Baik sekali \\
\hline
\end{tabular}

Sumber : Hasil penelitian yang diolah

Berdasarkan hasil pengolahan data penelitian yang terdapat pada Tabel 7 dapat diketahui bahwa persepsi guru pamong terhadap kemampuan mahasiswa PLK dalam berinteraksi dengan peserta didik secara komunikaif dengan baik sekali dan mampu memotivasi peserta didik dengan baik sekali. 
Berdasarkan hasil kajian penelitian pada sekolah tempat pelaksanaan PLK mahasiswa program studi Pendidikan Biologi UMMY Solok Tahun Pelajaran 2016-2017 menunjukkan bahwa secara umum Guru Pamong memiliki persepsi yang baik terhadap kompetensi profesional mahasiswa PLK yang dibimbingnya. Kemampuan dasar profesional guru yaitu kemampuan dalam menguasai bahan pengajaran, pengelolaan proses belajar mengajar, menilai prestasi belajar peserta didik, mengelola kelas, penggunaan media belajar dan interaksi belajar mengajar (Zainal, 2010: 102108).

Kompetensi pertama yang harus dimiliki seorang guru adalah penguasaan bahan pelajaran. Mahasiswa PLK sebagai calon guru sudah dibekali dengan materi perkuliahan, baik mata kuliah dibidang Biologi maupun matakuliah bidang pendidikan dan mata kuliah umum. Seperti yang diungkapkan Lukmanul (2011: 248) bahwa seorang guru harus memiliki pengetahuan yang baik mengenai subjek yang diajarkannya, menguasai materi, struktur, konsep dan pola pikir keilmuan yang mendukung mata pelajaran yang diampu.
Kenyataan di lapangan menunjukkan bahwa para Guru Pamong memandang para mahasiswa yang diasuhnya telah memiliki kemampuan yang baik sekali dalam menyesuaikan materi yang disampaikan dengan tujuan pembelajaran, menyajikan materi secara sistematis, menyajikan pembahasan materi dengan pembelajaran dengan tepat, dan menyajikan materi yang didapat dari beragam sumber. Guru pamong juga beranggapan bahwa mahasiswa PLK juga sudah memiliki kemampuan yang baik dalam mengaitkan materi dengan pengetahuan lain yang relevan, perkembangan iptek dan kehidupan nyata.

Kompetensi yang kedua yang harus dimiliki seorang guru adalah kemampuan dalam melakukan pengelolaan proses pembelajaran. Proses pembelajaran yang dikelola dengan baik akan menghasilkan proses pembelajaran yang baik dan tujuan pembelajaran dapat dicapai dengan efektif. Pengelolaan pembelajaran dimulai dari menyusun rencana pembelajaran. Lukmanul (2011: viii) mengungkapkan bahwa proses pembelajaran yang baik hanya bisa 
diciptakan melalui perencanaan yang baik dan tepat dan guru yang baik akan selalu membuat perencanaan untuk kegiatan pembelajarannya.

Guru pamong memiliki persepsi yang baik sekali terhadap kemampuan mahasiswa PLK dalam menyusun rencana pembelajaran. Kemampuan dalam menyusun rencana pembelajaran ini ditinjau dari bagaiman mahasiswa mampu merumuskan indikator dan tujuan pembelajaran, mengorganisasikan materi ajar sesaui dengan tujuan pembelajaran, memilih pendekatan, model dan metode yang sesuai dengan tujuan pembelajaran, karakteristik materi dan karakteristik peserta didik, kemampuan mahasiswa dalam menyusun skenario pembelajaran, menetapkan alokasi waktu, dan menyusun rencana penilaian.

Perencanaan pembelajaran yang baik baru akan berhasil jika dilaksanakan dengan tepat dalam proses pembelajaran. Pelaksanaan proses pembelajaran dimulai dari kegiatan pendahuluan, inti dan penutup. Proses pembelajaran yang dilakukan disesuaikan dengan pendekatan, model dan metode serta skenario yang sudah disusun dalam rencana pembelajaran. Mahasiswa PLK sebagai calon guru juga harus memiliki keterampilan-keterampilan dasar dalam melaksanakan pembelajaran seperti yang diungkapkan dalam Zainal (2010:101-102) diantaranya yaitu keterampilan membuka dan menutup pembelajaran, bertanya, memberikan penguatan, peringatan, mengadakan variasi, menjelaskan, membimbing diskusi, mengelola kelas dan memberikan umpan balik. Berdasarkan hasil penelitian yang sudah dilakukan, Guru Pamong menunjukkan persepsi yang baik sekali terhadap kemampuan mahasiswa PLK dalam melaksanakan proses pembelajaran. Hal ini tidak terlepas dari peran penting Guru Pamong yang sudah memberikan bimbingan dengan baik dalam melatih mahasiswa PLK dalam mempraktekkan kegiatan mengajarnya.

Kemampuan yang keempat yang harus dimiliki oleh seorang guru adalah kemampuan dalam melakukan penilaian terhadap prestasi belajar peserta didik. Penilaian harus dipandang sebagai salah satu faktor penting yang menentukan keberhasilan proses dan hasil belajar, bukan hanya sebagai cara yang digunakan untuk menilai hasil belajar. Kegiatan penilaian harus dapat memberikan 
informasi kepada guru untuk meningkatkan kemampuan mengajarnya dan membantu peserta didik mencapai perkembangan belajarnya secara optimal (Zaenal, 2009:5). Kegiatan penilaian yang dilakukan mahasiswa PLK dimulai dari menyusun rencana penilaian, melaksanakan penilaian, mengolah dan menganalisis serta membuat laporan penilaian, dan melaksanakan tindak lanjut hasil penilaian. Berdasarkan indikator tersebut, guru pamong memiliki persepsi yang baik sekali tentang kemampuan mahasiswa PLK dalam menilai prestasi belajar peserta didik.

Kemampauan yang keempat yang harus dimiliki oleh guru adalah kompetensi dalam melakukan pengelolaan kelas. Mahasiswa PLK sebagai calon guru oleh Guru Pamong dipandang sudah memiliki kemampuan yang baik dalam melakukan pengelolaan kelas. Baik dalam hal mengatur tata ruang kelas untuk pengajaran maupun dalam menciptakan iklim belajar yang kondusif sehingga proses pembelajaran dapat berjalan optimal. Kemampuan guru dalam mengelola kelas sangat menentukan terhadap lancarnya pelaksanaan proses pembelajaran. Hal ini sesuai dengan apa yang diungkapkan oleh Zainal (2010:82) bahwa peran guru sangat besar dalam pengelolaan kelas karena guru sebagai penanggung jawab kegiatan belajar mengajar di kelas. Guru harus penuh inisisatif dan kreatif dalam mengelola kelas karena gurulah yang mengetahui secara pasti situasi dan kondisi kelas terutama kondisi siswa dengan segala latarbelakangnya.

Kemampuan yang kelima yang harus dimiliki oleh seorang guru adalah kemampauan dalam menggunakan media pembelajaran. Guru Pamong memiliki persepsi yang baik terhadap kemampuan mahasiswa PLK dalam menggunakan media pembelajaran. Karena mahasiswa dinilai sudah mampu mengenal, memilih dan menggunakan media pembelajaran, membuat alat bantu belajar sederhana dan menggunakan fasilitas pendukung dalam pengajaran. Kemampuan ini sangat dibutuhkan oleh seorang guru agar bisa membantu dalam pelaksanaan proses pembelajaran. Hamalik (1986) dalam Azhar (2010:15-16), mengemukakan bahwa pemakaian media pembelajaran dalam proses belajar mengajar dapat membangkitkan 
keinginan dan minat yang baru, membangkitkan motivasi dan ransangan kegiatan belajar, dan bahkan membawa pengaruh-pengaruh psikologis terhadap siswa. Penggunaan media pembelajaran pada tahap orientasi pembelajaran akan sangat membantu keefekifan proses pembelajaran dan penyampaian pesan dan isi pelajaran pada saat itu.

Kompetensi yang keenam yang juga harus dimiliki oleh seorang guru adalah kemampuan dalam melakukan interaksi belajar mengajar dengan peserta didik. Guru Pamong memiliki persepsi yang baik sekali terhadap kemampuan mahasiswa PLK dalam berinteraksi dengan peserta didik secara komunikatif serta dapat memotivasi peserta didik dalam belajar. Kenyamanan dalam proses pembelajaran juga sangat dipengaruhi oleh bagaimana hubungan antara guru dengan peserta didik. Sumiati dan Asra (2011: 69), menjelaskan bahwa agar tercipta hubungan antar guru dan peserta didik secara lebih akrab dan menguntungkan, terutama dalam situasi akademik, guru dan peserta didik harus mempunyai sikap saling mengenali, bersikap terbuka, saling percaya dan menghargai dan memiliki kesungguhan hati mau membimbing peserta didik dan peserta didik pun dengan berkesungguhan hati mau dibimbing.

Berdasarkan enam kompetensi profesional mahasiswa PLK yang diamati oleh Guru Pamong, secara umum Guru Pamong memiliki persepsi yang baik. Kompetensi profesional yang dimiliki mahasiswa PLK adalah hasil dari usaha mahasiswa PLK dalam belajar dan latihan selama kegiatan perkuliahan dan PLK. Dan juga tidak terlepas dari bimbingan dan arahan dari dosen, Guru Pamong dan majelis guru yang ada di sekolah tempat pelaksanaan PLK.

\section{SIMPULAN}

Berdasarkan hasil penelitian dapat disimpulan bahwa persepsi Guru Pamong terhadap kompetensi profesional mahasiswa PLK program studi Pendidikan Bologi UMMY Solok pada tahun ajaran 2016-2017, yaitu meliputi kemampuan: Menguasai bahan termasuk kategori baik sekali; Mengelola proses belajar mengajar termasuk kategori baik sekali; Menilai prestasi belajar peserta didik termasuk kategori baik sekali; Mengelola kelas termasuk kategori baik sekali; 
Menggunakan media dan sumber belajar termasuk kategori baik; Mengelola interaksi belajar mengajar termasuk kategori baik sekali.

\section{DAFTAR PUSTAKA}

Anonim. 2010. Buku Pedoman Praktek Lapangan Kependidikan. UMMY Solok.

Arikunto, S. 2007. Manajemen Penelitian. Jakarta: RinekaCipta. 2009. Dasar-dasar Evaluasi Pendidikan Edisi Revisi. Jakarta: PT Bumi Aksara.

Asril, Z. 2010. Micro Teaching. Jakarta: PT Raja GrafindoPersada.

Azhar, A. 2010. Media Pembelajaran. Jakarta: PT Raja Grafindo Persada.
Hamalik, O. 2008. Pendidikan Guru Berdasarkan Pendekatan Kompetensi. Jakarta: BumiAksara.

Lukmanul, H. 2011. Perencanaan Pembelajaran. Bandung : CV Wacana Prima.

Sumiati dan Asra. 2011. Metode Pembelajaran. Bandung: CV Wacana Prima.

Zaenal, A. 2009. Evaluasi Pembelajaran. Bandung: PT Remaja Rosdakarya.

Siagian. 2004. Teori Motivasi dan Aplikasinya. Jakarta: PT. Rineka Cipta.

Wardani dan Anah SS. 1994. Program Pengalaman Lapangan( $P P L)$. Jakarta: Departemen Pendidikan dan Kebudayaan. 